\title{
Systematic review of infant and young child complementary feeding practices in South Asian families: the Pakistan perspective
}

\author{
Logan Manikam ${ }^{1, *}$, Anika Sharmila ${ }^{2}$, Abina Dharmaratnam ${ }^{3}$, Emma C Alexander $^{2}$, Jia \\ Ying Kuah ${ }^{2}$, Ankita Prasad ${ }^{2}$, Sonia Ahmed' ${ }^{1}$, Raghu Lingam ${ }^{4}$ and Monica Lakhanpaul ${ }^{1}$ \\ 'Population, Policy \& Practice, UCL Great Ormond Street Institute of Child Health, 30 Guilford Street, London WCIN 1EH, \\ UK: ${ }^{2}$ King's College Hospital, King's College Hospital NHS Foundation Trust, London, UK: ${ }^{3}$ Leicester Medical School, \\ University of Leicester, Leicester, UK: ${ }^{4}$ Institute of Health \& Society, Newcastle University, Newcastle upon Tyne, UK
}

Submitted 8 November 2016: Final revision received 30 August 2017: Accepted 1 September 2017: First published online 20 November 2017

\begin{abstract}
Objective: Suboptimal nutrition among children remains a problem among South Asian (SA) families. Appropriate complementary feeding (CF) practices can greatly reduce this risk. Thus, we undertook a systematic review of studies assessing $\mathrm{CF}$ (timing, dietary diversity, meal frequency and influencing factors) in children aged $<2$ years in Pakistan.

Design: Searches between January 2000 and June 2016 in MEDLINE, EMBASE, Global Health, Web of Science, OVID Maternity \& Infant Care, CINAHL, Cochrane Library, BanglaJOL, POPLINE and WHO Global Health Library. Eligibility criteria: primary research on $\mathrm{CF}$ practices in SA children aged 0-2 years and/or their families. Search terms: 'children', 'feeding' and 'Asians' with their derivatives. Two researchers undertook study selection, data extraction and quality appraisal (EPPI-Centre Weight of Evidence).

Results: From 45712 results, seventeen studies were included. Despite adopting the WHO Infant and Young Child Feeding guidelines, suboptimal CF was found in all studies. Nine of fifteen studies assessing timing recorded CF introduced between 6 and 9 months. Five of nine observed dietary diversity across four of seven food groups; and two of four, minimum meal frequency in over $50 \%$ of participants. Influencing factors included lack of CF knowledge, low maternal education, socio-economic status and cultural beliefs.

Conclusions: This is the first systematic review to evaluate CF practices in Pakistan. Campaigns to change health and nutrition behaviour are needed to meet the substantial unmet needs of these children.
\end{abstract}

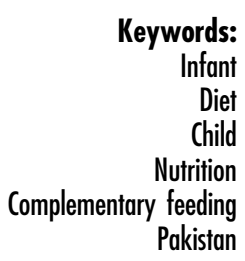

Pakistan is one of the worst performers in child mortality in the world, with an under- 5 mortality rate of 81 per 1000 live births in $2015^{(1)}$. Widespread malnutrition is reported in over $50 \%$ of children living in Pakistan ${ }^{(2)}$. Both over- and undernutrition are prevalent within Pakistani families, with coexisting nutrition-related diseases; while $45 \%$ of children have stunted growth, $40 \%$ of Pakistani school-aged children are overweight ${ }^{(3-7)}$. Good feeding practices in early childhood should be a key area of focus to prevent malnutrition and measures to improve complementary feeding (CF) have been recommended for future investment ${ }^{(8-10)}$.

The WHO defines CF as: 'The process starting when breast milk alone is no longer sufficient to meet the nutritional requirements of infants, and therefore other foods and liquids are needed, along with breast milk ${ }^{,(11)}$. CF therefore focuses on bridging the gradual transition between 6 and 24 months from exclusive breast-feeding to solid foods eaten by the whole family alongside breast-feeding. An appropriate diet following WHO guidelines in the first 2 years with breast-feeding and CF can decrease all-cause childhood mortality by approximately $20 \%$ in low-income countries ${ }^{(9)}$. It can also guarantee sufficient nutritional intake, reducing obesogenic dietary behaviours while ensuring healthy gain of weight in children ${ }^{(8)}$.

The 2010 WHO Infant and Young Child Feeding (IYCF) guidelines, an internationally ratified framework adopted in Pakistan, emphasize as a global public health recommendation that infants should be exclusively breastfed for the first 6 months of life. Thereafter, infants should 
receive safe and nutritionally adequate complementary foods while breast-feeding continues for up to 2 years of age or beyond ${ }^{(12)}$. The period from 6 months to 24 months of age is a critical and vulnerable period of infant growth ${ }^{(13)}$.

Current literature shows that knowledge of infant feeding practices and $\mathrm{CF}$ is lacking among Pakistani families, with Demographic and Health Survey (DHS) data from Pakistan highlighting inadequate breast-feeding and complementary feeding practices $(\mathrm{CFP})^{(14,15)}$. The Pakistan DHS has only recently begun collecting information on all IYCF indicators, so an examination of these factors is particularly important ${ }^{(16,17)}$.

The present systematic review is part of a large project exploring the adequacy of CFP based on IYCF recommended minimum dietary diversity and meal frequency, timing of introducing $\mathrm{CF}$, and barriers and promoters influencing CFP among South Asians (SA). SA communities have fundamental differences in geography and religion, which both influence feeding practices. As such, the current review is one of four looking at CFP in Pakistan, India, Bangladesh, and SA living in high-income countries. The work aims to inform future projects to develop and evaluate culturally appropriate interventions to improve CFP across SA families in these different communities.

\section{Methods}

The present review (PROSPERO registration number CRD42014014025) summarizes publications on CFP in SA families in Pakistan only, with concurrent reviews summarizing publications on CFP in SA families in India ${ }^{(18)}$, Bangladesh $^{(19)}$ and high-income countries (L Manikam, R Lingam, I Lever et al., unpublished results), respectively.

\section{Eligibility criteria}

Studies were included if they met the following criteria.

- Participants: children aged 0-2 years, parents, carers and/or their families.

- Outcomes: adequacy of CF (based on minimum dietary diversity and meal frequency), timing of introduction of $\mathrm{CF}$ and barriers/promoters to incorporating WHO recommended CFP.

- Language: studies published in English, or with translation available.

- Year: published from 2000 or later.

In the IYCF indicators, introduction of CF is assessed as the proportion of infants aged 6-8 months who receive solid, semi-solid or soft foods ${ }^{(20)}$. In contrast, minimum dietary diversity (MDD) is assessed by the proportion of infants 6-23 months of age who receive foods from four or more food groups. The seven WHO IYCF recommended food groups are ${ }^{(20)}$ :

1. grains, roots and tubers;

2. legumes and nuts;
3. dairy products (e.g. milk, yoghurt, cheese);

4. flesh foods (e.g. meat, fish, poultry and liver/organ meats);

5. eggs;

6. vitamin A-rich fruits and vegetables; and

7. other fruits and vegetables.

While the consumption of Fe-rich or Fe-fortified foods is commonly assessed as a separate IYCF indicator, this was incorporated within dietary diversity for ease of interpretation in the current review.

Finally, minimum meal frequency (MMF) is assessed by the proportion of breast-fed and non-breast-fed children 6-23 months of age who receive solid, semi-solid or soft foods (also including milk feeds for non-breast-fed children) the minimum number of times or more per day: two times for 6-8 months, three times for 9-23 months and four times for 6-23 months (if not breast-fed) ${ }^{(20)}$.

All study types (qualitative/quantitative/mixed) were included to ensure the diversity of evidence was captured and summarized, to be of relevance to both policy makers and health and social care professionals. We excluded studies focusing solely on exclusive breast-feeding and interventional studies.

\section{Information sources}

We searched the following databases: MEDLINE, EMBASE, Global Health, BanglaJOL, CINAHL, Web of Science, OVID Maternity \& Infant Care, The Cochrane Library, POPLINE and WHO Global Health Library. Searches were conducted in December 2014 and updated in June 2016.

Members of electronic networks on @jiscmail.ac.uk including minority-ethnic-health and networks (e.g. South Asian Health Foundation) developed from the Specialist Electronic Library for Ethnicity and Health were contacted to request any additional or unpublished material from members of the networks. Bibliographies of included articles were also hand-searched for additional publications.

\section{Search strategy}

The search strategy included terms for 'feeding', 'South Asian' (including terms specifying all major subgroups as below) and 'children'. For example, the search strings used for MEDLINE were the following.

Term 1: children $<2$ years

Infant OR Baby OR Babies OR Toddler OR Newborn OR Neonate* OR Child OR Preschool OR Nursery school OR Kid OR Paediatric* OR Minors OR Boy OR Girl

Term 2: feeding
Nutritional Physiological Phenomena OR Food OR Feeding behaviour OR Feed OR Nutrition OR Wean OR fortify* OR Milk 
Term 3: Asians

Ethnic* OR India* OR Pakistan* OR Bangladesh* OR Sri Lanka OR Islam OR Hinduism OR Muslim OR Indian subcontinent OR South Asia

\section{Study selection and data extraction}

In total, 45712 titles and abstracts were screened against inclusion criteria. Two reviewers assessed these papers independently and conflicts were resolved by discussion with the team. In view of the large number of articles deemed eligible for full-text review, articles published before the year 2000 were excluded. In total, 44852 titles and abstracts were excluded.

This left 860 articles describing CFP in SA children for fulltext review by two independent reviewers. One hundred and thirty-one full-text articles were ultimately extracted, of which seventeen were sufficiently relevant to Pakistan.

Data were extracted by a single reviewer using a piloted modified worksheet including: country of study; study type; study year; study objectives; population studied, eligibility criteria and illness diagnosis; study design; ethical approval; sampling; data collection and analysis; feeding behaviours; adequacy of CFP; timing of initiation of CF; bias; value of the research; and weight of evidence. A second member of the research team checked each extraction.

\section{Result synthesis}

The eligible studies tended to address broad research questions, were conducted using qualitative and/or quantitative and/or descriptive methods, and were not presented following standardized reporting guidelines (i.e. STROBE (Strengthening the Reporting of Observational Studies in Epidemiology) for observational studies or COREQ (Consolidated Criteria for Reporting Qualitative Research) for qualitative research). Meta-analyses were therefore not undertaken.

To standardize study classifications, the formal definitions below were applied.

1. Interventional study: a study in which patients are assigned to a treatment group or a comparison group and followed prospectively.

2. Cohort study: an observational study in which a group of patients are followed over time. These may be prospective or retrospective.

3. Cross-sectional study: an observational study that examines the relationship between health-related characteristics and other variables of interest in a defined population at one particular time.

4. Case-control study: a study that compares patients who have a disease or outcome of interest (cases) with patients who do not have the disease or outcome of interest (controls).

5. Qualitative: a study which aims to explore the experiences or opinions of families through interviews, focus groups, reflective field notes and other nonquantitative approaches.

6. Mixed methods: a study that combines both quantitative and qualitative methodology.

In view of the studies' heterogeneity regarding methodology, participants, interventions and outcomes, a narrative approach to synthesis was utilized using guidance developed from the University of York Centre for Reviews and Dissemination (CRD) and the Economic and Social Research Council (ESRC) ${ }^{(21-24)}$.

The evidence reviewed is presented as a narrative report, with the results categorized following IYCF indicators on: (i) adequacy of CFP, comprising dietary diversity, consumption of Fe-rich foods, meal frequency, timing of introduction of CFP, food hygiene and sources of advice for feeding; and (ii) barriers/promoters influencing CFP.

Barriers were defined as obstacles or impediments to achieving correct CFP, while promoters were defined as supporters to achieving correct CFP. These were sub-categorized into factors influencing at the family level (e.g. family members) and the organizational level (e.g. health-care providers, hospitals, political bodies).

\section{Quality assurance}

The CRD guidance emphasizes the importance of using a structured approach to quality assessment when assessing descriptive or qualitative studies for inclusion in reviews. However, it acknowledges the lack of consensus on the definition of poor quality with some arguing that using rigid quality criteria leads to the unnecessary exclusion of papers $^{(21)}$.

In our review, the EPPI-Centre Weight of Evidence Framework was used to allow for objective judgements about the value of each study in answering the review question $^{(25)}$. It examines three study aspects: quality of methodology, relevance of methodology and relevance of evidence to the review question, and categorizes them into 'low' (L), 'medium' (M) or 'high' (H). The overall weight of evidence (WOE), i.e. the overall assessment of the extent to which the study provides evidence to answer the review question, is also rated as $\mathrm{L}, \mathrm{M}$ or $\mathrm{H}$. Two independent reviewers performed this evaluation, with additional arbitration by other team members where required. One study with an overall $\mathrm{WOE}=\mathrm{L}$ is included in the table summarizing included studies but is not discussed further within the 'Results' or 'Discussion' section below.

\section{Results}

Of the 45712 studies identified, seventeen studies focusing on CFP in Pakistan were ultimately included in the current systematic review. The study selection process is denoted in Fig. 1. 


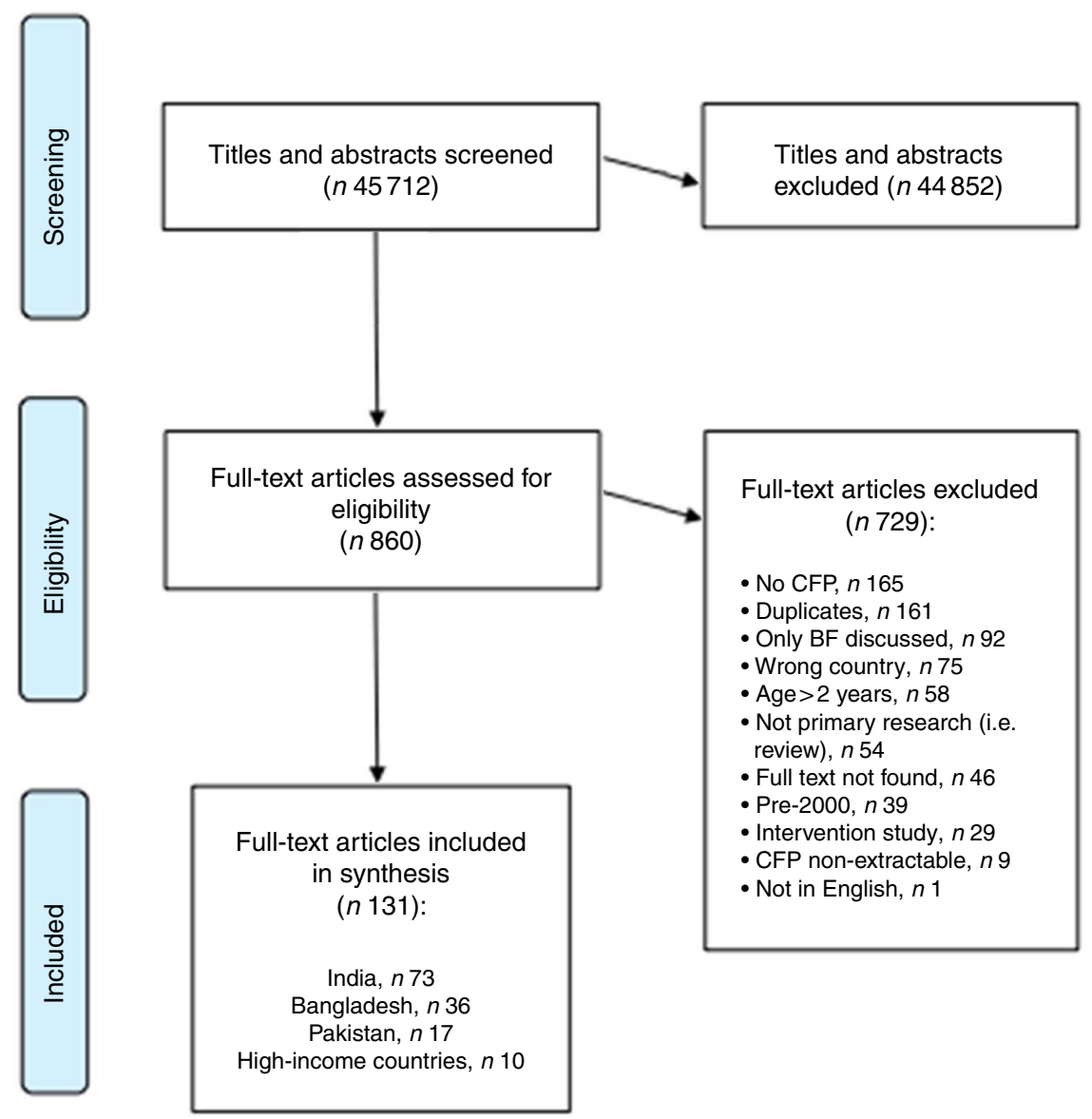

Fig. 1 Study selection process for the current systematic review (CFP, complementary feeding practices; BF, breast-feeding)

\section{Study and participant characteristics}

These seventeen studies consisted of fourteen crosssectional studies, two qualitative studies and one cohort study. Table 1 summarizes all included studies. Figure 2 illustrates the study locations of fourteen of these seventeen included studies, with the remaining three not detailing precise study locations.

Table 2 presents the weight of evidence awarded to each of the studies. The core narrative themes extracted from the papers are presented under the following headings: (i) adequacy of CFP and (ii) factors associated with CFP.

\section{Adequacy of complementary feeding practices}

As per the WHO IYCF indicators, adequacy of CFP is assessed according to dietary diversity, meal frequency and timing of introducing CFP. These are detailed in the subsections below, with three further subsections discussing Fe-rich foods, food hygiene and advice providers.

\section{Dietary diversity}

Dietary diversity was explored in nine studies, with food consumption recall being the commonest way to assess MDD. Most studies did not provide precise rates of the population being fed with each food group, and no study properly assessed rates of achieved MDD across four of the seven WHO IYCF food groups defined above.

Table 3 denotes a summary of all complementary food groups identified from the studies. Of the nine studies with data relevant to MDD, five studies described CFP involving four of the seven food groups ${ }^{(26-30)}$. Overall, Pakistani CF diets were described as being based largely on grains and legumes by Lingam et al. $(\mathrm{WOE}=\mathrm{H})^{(31)}$. Shamim et al. $(\mathrm{WOE}=\mathrm{M}$ ) observed frequent poor dietary diversity, with even those who were fed recommended weaning items (including home-made cereals, egg, banana and fish) having a high prevalence of stunting (31.4\%), wasting $(20 \cdot 3 \%)$ and underweight $(46 \cdot 4 \%)^{(30)}$.

In nine studies, the 'grains, roots and tubers' food group was utilized for CFP. Eight named 'other fruits and vegetables', six mentioned 'legumes and nuts', five studies included 'dairy products', four studies 'flesh foods' and four studies 'eggs'. No studies mentioned 'vitamin A-rich fruits and vegetables'.

'Grains, roots and tubers' were most commonly mentioned as being used for $\mathrm{CF}$, included in nine studies. Sarwar $($ WOE $=\mathrm{H})$ observed that $42 \%$ of sampled children aged 3-12 months were first introduced to CF with cereal, 
Table 1 Summary of studies included in the current systematic review

\begin{tabular}{|c|c|c|c|c|c|}
\hline Study & Study type & Location & Population & Sample size & Key findings \\
\hline $\begin{array}{l}\text { Ahmed et al. } \\
\qquad(2001)^{(32)}\end{array}$ & Cross-sectional & Oghi, Pakistan & $\begin{array}{l}\text { Mothers of children } \\
\text { attending the Tehsil } \\
\text { Headquarter Hospital } \\
\text { of Oghi }\end{array}$ & $\begin{array}{l}\text { Ten mothers from test } \\
\text { epicentre }\end{array}$ & $\begin{array}{l}\text { Diversity: Milk delivered can include cow's milk, formula, mixed milk. CF foods include } \\
\text { banana, cereals, apple, home-made semi-solid foods } \\
\text { Introduction to CF: } 10 \% \text { with cereal, } 30 \% \text { fruits, } 10 \% \text { cow's milk. For current feeds: } 20 \% \\
\text { with cereal, } 30 \% \text { apples, } 30 \% \text { bananas, } 10 \% \text { cow's milk } \\
\text { Advice: Knowledge is transferred from one generation of women to the other in the } \\
\text { household, advice also comes from women's magazines, radio and television } \\
\text { Factors: Lack of knowledge, especially where there are fewer babies, is a barrier }\end{array}$ \\
\hline $\begin{array}{l}\text { Dev et al. } \\
\qquad(2013)^{(34)}\end{array}$ & Cross-sectional & Karachi, Pakistan & $\begin{array}{l}\text { Bilal Colony and Bhains } \\
\text { Colony }\end{array}$ & $\begin{array}{l}355 \text { mothers of } \\
\text { children aged } \\
<2 \text { years across } \\
\text { two sites }\end{array}$ & $\begin{array}{l}\text { Diversity: Bilal mothers used home food preparations more often than Bhains mothers. } \\
93.0 \% \text { of home-made foods given in by sampled mothers in Bhains in Karachi } \\
\text { contained kitchri (rice and pulses), as did } 42.6 \% \text { of home-made foods given in Bilal. } \\
21 \% \text { of mothers in Bilal provided only shop-bought/processed complementary foods } \\
\text { v. } 37 \% \text { in Bhains. Various combinations of mashed potato, banana, khichri, sago } \\
\text { dana, dalia and others } \\
\text { Frequency: In Bilal, } 48.3 \% \text { fed } 3+\text { times } / \mathrm{d} \text {, Bhains } 35.7 \% \text { fed } 3+\text { times/d; and } \\
10.2 \text { and } 9.5 \% \text { only } 1 \text { time/d } \\
\text { Timing: In Bilal, } 19.9 \% \text { before } 6 \text { months, } 27.8 \% \text { at } 6 \text { months, } 27.3 \% \text { at } 7-11 \text { months, } \\
15.3 \% \text { at } 1-2 \text { years; in Bhains, } 36 \cdot 3,5.0,26 \cdot 3 \text { and } 18.4 \% \text {, respectively (others 'don't } \\
\text { know') } \\
\text { Advice: Cultural norms are spread within families, which may conflict with advice from } \\
\text { health workers } \\
\text { Factors: Difficulty with feeding was a barrier, also lack of knowledge. NGO activity } \\
\text { increased knowledge }\end{array}$ \\
\hline $\begin{array}{l}\text { Dykes et al. } \\
\qquad(2012)^{(33)}\end{array}$ & Cohort & $\begin{array}{l}\text { Nahaqi in Khyber } \\
\text { Pakhtoonkhwa } \\
\text { (KP), Pakistan }\end{array}$ & $\begin{array}{l}\text { Women health workers in } \\
\text { communities served by } \\
\text { the Emergency } \\
\text { Satellite Hospital in } \\
\text { Nahaqi, KP }\end{array}$ & $\begin{array}{l}\text { Sixteen local women } \\
\text { health workers }\end{array}$ & $\begin{array}{l}\text { Diversity: Weaning foods include roti (bread), rice, potato and banana } \\
\text { Timing: Commencement of CF before } 6 \text { months is common, categorized } 3-6 \text { months } \\
\text { Factors: Poverty stops women from affording e.g. milk, meat, fruits; affordability limits } \\
\text { ability to provide 'healthy' foods; and insufficient milk causes early CF. If a mother } \\
\text { becomes pregnant she is likely to cease breast-feeding or space feeds out }\end{array}$ \\
\hline Hanif $(2011)^{(14)}$ & Cross-sectional & Pakistan & $\begin{array}{l}\text { Evaluation survey using } \\
\text { data from across } \\
\text { Pakistan }\end{array}$ & $\begin{array}{l}168332 \text { households } \\
\text { in Pakistan from } \\
1990 \text { to } 2008\end{array}$ & $\begin{array}{l}\text { Timing: Introduction of CF foods was rated as 'poor' relative to WHO indicators; this was } \\
\text { also the case for bottle-feeding and early initiation of breast-feeding. } 32 \cdot 1 \text { and } 36 \cdot 3 \% \\
\text { were having CF at } 6-9 \text { months in } 1990-91 \text { v. } 2006-07\end{array}$ \\
\hline $\begin{array}{l}\text { Hazir et al. } \\
\qquad(2012)^{(15)}\end{array}$ & Cross-sectional & $\begin{array}{l}\text { Urban and rural } \\
\text { Pakistan }\end{array}$ & $\begin{array}{l}\text { Pakistan Demographic } \\
\text { and Health Survey } \\
\text { 2006-07 participants }\end{array}$ & 941 infants & $\begin{array}{l}\text { Timing: Over } 50 \% \text { of infants were not receiving soft, semi-solid or solid foods at the } \\
\text { recommended time; } 10 \% \text { of } 3-5 \text {-month-olds commenced CF earlier than the } \\
\text { recommended } 6 \text { months. Early CF was related to } 4+\text { antenatal visits and there were } \\
\text { geographical variations. Urban respondents were more likely to engage in early and } \\
\text { timely CF, with } 13.8 \% \text { giving CF at } 3-5 \text { months and at } 56.6 \% \text { at } 6-8 \text { months. Only } \\
9.1 \% \text { of rural respondents gave CF at } 3-5 \text { months, and only } 33.2 \% \text { at } 6-8 \text { months } \\
\text { Factors: Literate mothers, those with high levels of education, with many antenatal visits, } \\
\text { from urban households and from wealthy households were more likely to practise } \\
\text { appropriate CF. Mothers in employment, with fewer antenatal visits, from rural } \\
\text { households, and in the Baluchistan and Sindh regions were less likely to practise } \\
\text { appropriate CF. Risk of not introducing CF at the recommended age was higher with } \\
\text { increased parity. Generally, as wealth index increased, so too did appropriate CF } \\
\text { timing }\end{array}$ \\
\hline $\begin{array}{l}\text { Krebs et al. } \\
\qquad(2011)^{(26)}\end{array}$ & Cross-sectional & $\begin{array}{l}\text { Urban Karachi, } \\
\text { Pakistan (together } \\
\text { with Zambia, } \\
\text { Guatemala and } \\
\text { Democratic } \\
\text { Republic of Congo) }\end{array}$ & Clinic visitors in Karachi & $\begin{array}{l}531 \text { infants aged } \\
5-9 \text { months and } \\
516 \text { toddlers aged } \\
12-24 \text { months }\end{array}$ & $\begin{array}{l}\text { Diversity: Meat is consumed often by under } 25 \% \text { of infants; over } 50 \% \text { receive fish, eggs } \\
\text { or dairy regularly; } 23.3 \% \text { are fed formula regularly. Legumes (beans and lentils), } \\
\text { groundnuts (peanuts), meat, fish, eggs, dairy used } \\
\text { Frequency: } 50 \% \text { given } 1-2 \text { types of CF/d and } 37.7 \% \text { receive CF } 3+\text { times/d } \\
\text { Factors: The cost of meat is a barrier, although modest amounts seem to be available in } \\
\text { most households }\end{array}$ \\
\hline
\end{tabular}




\begin{tabular}{|c|c|c|c|c|c|}
\hline Study & Study type & Location & Population & Sample size & Key findings \\
\hline $\begin{array}{l}\text { Liaqat et al. } \\
\qquad(2007)^{(13)}\end{array}$ & Cross-sectional & Islamabad, Pakistan & $\begin{array}{l}\text { Patients attending } \\
\text { Outpatient Paediatrics } \\
\text { Department of Federal } \\
\text { Government Services } \\
\text { Hospital, Islamabad }\end{array}$ & $\begin{array}{l}500 \text { mothers of } \\
\text { infants aged } \\
6-24 \text { months }\end{array}$ & $\begin{array}{l}\text { Timing: CF starts as late as } 12 \text { months among } 64 \% \text { of uneducated respondents, } v .17 \% \\
\text { of educated respondents. Also, early at } 3-6 \text { months and } 6-9 \text { months optimal practice } \\
\text { Advice: The extended family has an important role in supporting the mother and caring } \\
\text { for the children } \\
\text { Factors: Maternal education is positively linked to good CF practices, including } \\
\text { appropriately timed initiation. Poverty is a key reason for inappropriate CF }\end{array}$ \\
\hline $\begin{array}{l}\text { Lingam et al. } \\
\qquad(2014)^{(31)}\end{array}$ & Qualitative & $\begin{array}{l}\text { Rawalpindi district in } \\
\text { Pakistan (and rural } \\
\text { Udaipur district of } \\
\text { Rajasthan in India) }\end{array}$ & $\begin{array}{l}\text { Patients in Rawalpindi } \\
\text { district }\end{array}$ & Sixty-nine contacts & $\begin{array}{l}\text { Diversity: Diet is commonly based on grains and legumes. Cerelac, a store-bought } \\
\text { porridge, was common among affluent families and used with boiled potato and } \\
\text { banana. Kitchri is used for weaning with pulses and rice pudding } \\
\text { Timing: Weaning started between } 4 \text { and } 8 \text { months } \\
\text { Factors: Familial wealth was the main predictive factor for the age at introduction, } \\
\text { interaction while feeding and dietary content of CF. Poorer households were less likely } \\
\text { to have appropriate CF. Cultural beliefs had a large influence on CF. Parenting support } \\
\text { important }\end{array}$ \\
\hline $\begin{array}{l}\text { Mehkari et al. } \\
\quad(2014)^{(27)}\end{array}$ & Cross-sectional & $\begin{array}{l}\text { Tertiary care hospital } \\
\text { of Karachi, } \\
\text { Pakistan }\end{array}$ & $\begin{array}{l}\text { Female health-care } \\
\text { professionals working } \\
\text { at the hospital }\end{array}$ & Ninety-four mothers & $\begin{array}{l}\text { Diversity: } 85 \% \text { of mothers preferred home-made CF foods, } 15 \% \text { used commercial } \\
\text { preparations. Common CF food items included dayla (porridge, } 64 \% \text { ), kitchri (rice and } \\
\text { pulses, } 69 \% \text { ), kheer (rice with milk, } 48 \% \text { ) and mashed potato }(65 \%) \\
\text { Timing: } 78 \% \text { of mothers knew CF should be initiated at } 6 \text { months, } 53.2 \% \text { followed this } \\
\text { up in practice. Weaning also initiated at } 5 \text { and } 4 \text { months } \\
\text { Factors: Professional and employment-related issues resulted in early cessation of } \\
\text { breast-feeding }\end{array}$ \\
\hline $\begin{array}{l}\text { Memon et al. } \\
\qquad(2010)^{(36)}\end{array}$ & Cross-sectional & $\begin{array}{l}\text { Liaquat University } \\
\text { Hospital Jamshoro, } \\
\text { Hyderabad, } \\
\text { Pakistan }\end{array}$ & $\begin{array}{l}\text { Mothers of infants aged } \\
0-24 \text { months }\end{array}$ & 500 mothers & $\begin{array}{l}\text { Diversity: Of CF children aged } 6-11 \text { months (with } 24 \mathrm{~h} \text { recall), } 40 \text { (33\%) were given } \\
\text { specially prepared meals } \\
\text { Frequency: } 100 \text { ( } 50 \% \text { ) children aged } 12-23 \text { months received CF at appropriate } \\
\text { frequency of } 3-4 \text { times/d } \\
\text { Timing: } 21 \% \text { of } 2-3 \text {-month-olds received CF. } 50 \% \text { of } 12-23-\text { month-olds received } \\
3-4 \text { CF feeds/d, categorized }<3,3-6 \text { months } \\
\text { Advice: For } 78 \% \text { CF advice was given by family, for } 22 \% \text { by doctors and health workers } \\
\text { Factors: CF practices correlated with maternal education. Poorer households were more } \\
\text { likely to have inadequate feeding practices than well-to-do families. Some mothers } \\
\text { received incorrect advice from health workers. Mother getting pregnant resulted in } \\
\text { failure to breast-feed for full } 6 \text { months. Being poor rather than middle class had an } \\
\text { impact. Some initiated formula as breast milk was insufficient }\end{array}$ \\
\hline $\begin{array}{l}\text { Mohsin et al. } \\
\qquad(2014)^{(35)}\end{array}$ & Cross-sectional & $\begin{array}{l}\text { Outpatient } \\
\text { Department of } \\
\text { Pediatrics, Civil } \\
\text { Hospital, Karachi, } \\
\text { Pakistan }\end{array}$ & $\begin{array}{l}\text { Mothers attending } \\
\text { Outpatient Department } \\
\text { of Pediatrics, Civil } \\
\text { Hospital, Karachi }\end{array}$ & $\begin{array}{l}138 \text { mothers of } \\
\text { children aged } \\
\text { up to } 2 \text { years }\end{array}$ & $\begin{array}{l}\text { Diversity: Quality and quantity of CF often inadequate. } 46.4 \% \text { used commercial food, tea } \\
\text { used for CF } \\
\text { Frequency: CF frequency often inadequate; } 55.8 \% \text { fed solid foods } 3 \text { times } / \mathrm{d}, 39.9 \% \\
\text { twice/d, } 2.2 \% \text { once/d } \\
\text { Timing: } 84 \% \text { had knowledge that optimal time for CF was }<6 \text { months, only } 13 \% \mathrm{knew} \\
\text { about correct timing. CF was often started early. } 27.5 \% \text { considered }<4 \text { months to be } \\
\text { optimal, and } 57.2 \% 4-6 \text { months } \\
\text { Advice: Doctors were main source of information about commercial CF foods for } 52.9 \% \text {, } \\
\quad \text { v. friends and relatives for } 25.4 \% \text { and electronic media for } 17.4 \% \\
\text { Factors: Cultural beliefs about certain hot or cold foods; mothers unaware of appropriate } \\
\text { times for CF; lack of maternal time }\end{array}$ \\
\hline $\begin{array}{l}\text { Premji et al. } \\
\qquad(2014)^{(37)}\end{array}$ & Qualitative & $\begin{array}{l}\text { Ibrahim Haidery, Bin } \\
\text { Qasim town of } \\
\text { Karachi, Pakistan }\end{array}$ & $\begin{array}{l}\text { Families with infants less } \\
\text { than } 6 \text { weeks old }\end{array}$ & $\begin{array}{l}\text { Ten mothers, eight } \\
\text { fathers and four } \\
\text { grandmothers }\end{array}$ & $\begin{array}{l}\text { Timing: CF observed at }<3 \text { months, such as of sulemnai chai, and supplementing after } \\
40 \mathrm{~d} \\
\text { Advice: Extended family members are very important for support in resolving issues of } \\
\text { feeding and childcare. Elders outside the family were also consulted } \\
\text { Factors: Cultural influences played a big part in CF, particularly in introducing non- } \\
\text { breast-milk foods into diets before } 6 \text { months. Cultural beliefs can especially be spread } \\
\text { by elders }\end{array}$ \\
\hline
\end{tabular}


Table 1 Continued

\begin{tabular}{|c|c|c|c|c|c|}
\hline Study & Study type & Location & Population & Sample size & Key findings \\
\hline Sarwar $(2002)^{(28)}$ & $\begin{array}{l}\text { Cross-sectional } \\
\text { across two } \\
\text { countries }\end{array}$ & $\begin{array}{l}\text { Mian Channu, } \\
\text { Pakistan and } \\
\text { England, UK }\end{array}$ & $\begin{array}{l}\text { Pakistani mothers in } \\
\text { England and Pakistan } \\
\text { with children aged } \\
3-12 \text { months }\end{array}$ & $\begin{array}{l}\text { Ninety mothers } \\
\text { (forty-five living in } \\
\text { England and } \\
\text { forty-five in } \\
\text { Pakistan) }\end{array}$ & $\begin{array}{l}\text { Diversity: Family foods were used for CF in Pakistan, } v \text {. vegetables, sweet convenience } \\
\text { foods and meat in England. In Pakistan, first introduced to CF with: } 42 \% \text { cereal, } 49 \% \\
\text { rice, } 11 \% \text { fruits, } 11 \% \text { vegetables, } 20 \% \text { egg, } 2 \% \text { sweet convenience foods, } 2 \% \text { meat. } \\
\text { At time of study: } 84 \% \text { rice, } 29 \% \text { cereal, } 60 \% \text { fruits, } 47 \% \text { vegetables, } 44 \% \text { egg, } 11 \% \\
\text { savoury convenience foods, } 20 \% \text { sweet convenience foods, } 24 \% \text { meat. Tea was also } \\
\text { used for CF } \\
\text { Timing: } 40 \% \text { in Pakistan introduced solids at } 3-4 \text { months, } 26 \% \text { did not wean until } \\
7 \text { months or later } \\
\text { Advice: Most mothers, two-thirds, received advice on weaning from family and friends. } \\
\text { Health professionals also advised } \\
\text { Factors: Delayed CF occurred due to beliefs breast milk was nutritionally adequate. } \\
\text { Facilitating factors included booklets in English and Urdu, audio tapes in traditional } \\
\text { language, group discussions and clinic demonstrations, and integrating health } \\
\text { education into primary care }\end{array}$ \\
\hline $\begin{array}{l}\text { Senarath et al. } \\
(2012)^{(16)}\end{array}$ & Cross-sectional & Pakistan & $\begin{array}{l}\text { Mothers aged 12-49 } \\
\text { years of from most } \\
\text { recent Demographic } \\
\text { and Health Survey } \\
\text { data of Pakistan } \\
(2006-07)\end{array}$ & $\begin{array}{l}443 \text { infants aged } \\
6-8 \text { months }\end{array}$ & $\begin{array}{l}\text { Timing: Introduction of solid, semi-solid, or soft foods occurred for } 39 \% \text { of Pakistan } \\
\text { infants aged } 6-8 \text { months - low relative to other countries } \\
\text { Factors: Delayed CF was significantly more likely in poorer households relative to the } \\
\text { richest; birth order } 5+\text { also a barrier }\end{array}$ \\
\hline $\begin{array}{l}\text { Shamim } \\
\qquad(2005)^{(29)}\end{array}$ & Cross-sectional & $\begin{array}{l}\text { Peri-urban Karachi, } \\
\text { Pakistan }\end{array}$ & $\begin{array}{l}\text { Factory workers from } \\
\text { multiple ethnic groups } \\
\text { visiting 'Well Baby } \\
\text { Clinic' in Jinnah } \\
\text { Medical College } \\
\text { Hospital }\end{array}$ & 150 infants & $\begin{array}{l}\text { Diversity: Tea is used extensively in }>50 \% \text { of children. Kitchri, dayla and suji were also } \\
\text { used for CF. Banana only fruit offered for CF. Egg seldom used for CF. Frequent use of } \\
\text { milk-based cereal. } 52 \% \text { of mothers used commercial cereals. Meat almost never used } \\
\text { Timing: Mothers with worse education sometimes delayed CF until the infant was } 1 \text { year } \\
\text { old, general range within participants was } 3-9 \text { months } \\
\text { Advice: Family members and friends }(32 \%) \text {, media }(23 \%) \text {, medical/paramedical staff } \\
\text { (6.7\%) } \\
\text { Factors: Delayed CF was associated with low educational status of mothers, and with } \\
\text { larger family sizes and time pressure on mothers. Late weaning occurred in } 34.2 \% \text { of } \\
\text { those with parity }<3 \text { and } 59.6 \% \text { of those with parity } 3+\text {. Food was diluted to save } \\
\text { money. Custom/not enough breast milk also a factor }\end{array}$ \\
\hline $\begin{array}{l}\text { Shamim et al. } \\
\qquad(2006)^{(30)}\end{array}$ & Cross sectional & $\begin{array}{l}\text { Rural areas of } \\
\text { Malir district } \\
\text { in Karachi, } \\
\text { Pakistan }\end{array}$ & $\begin{array}{l}\text { Families living in Malir } \\
\text { district }\end{array}$ & $\begin{array}{l}359 \text { children under } \\
3 \text { years old }\end{array}$ & $\begin{array}{l}\text { Diversity: Two types of CF items observed - home-made food (home-made cereals, egg, } \\
\text { banana, fish) and commercial food (read-to-use cereals, biscuits and rusk). Even } \\
\text { those who ate the former group had high prevalence of malnourishment, stunting and } \\
\text { wasting. Kitchri, dalia, suji used for weaning. Fish is given regularly in fishing villages } \\
\text { but is too costly elsewhere } \\
\text { Timing: } 296 \text { were weaned between } 4 \text { and } 6 \text { months, sixty-three outside this range } \\
\text { Factors: Food affordability and access - banana is given due to its easy access, fish less } \\
\text { often due to expense }\end{array}$ \\
\hline $\begin{array}{l}\text { Sultana et al. } \\
\qquad(2011)^{(43)}\end{array}$ & Cross-sectional & Karachi, Pakistan & $\begin{array}{l}\text { Vaccination centre in the } \\
\text { Outpatient Department } \\
\text { of Paediatrics, Civil } \\
\text { Hospital }\end{array}$ & $\begin{array}{l}200 \text { children aged } \\
4-6 \text { months }\end{array}$ & $\begin{array}{l}\text { Timing: Direct relationship between education status of mother and children being } \\
\text { breast-fed for } 4 \text { months } \\
\text { Factors: Illiterate mothers or less educated mothers had inappropriately timed CF }\end{array}$ \\
\hline
\end{tabular}

CF, complementary feeding/complementary food; NGO, non-governmental organization. 


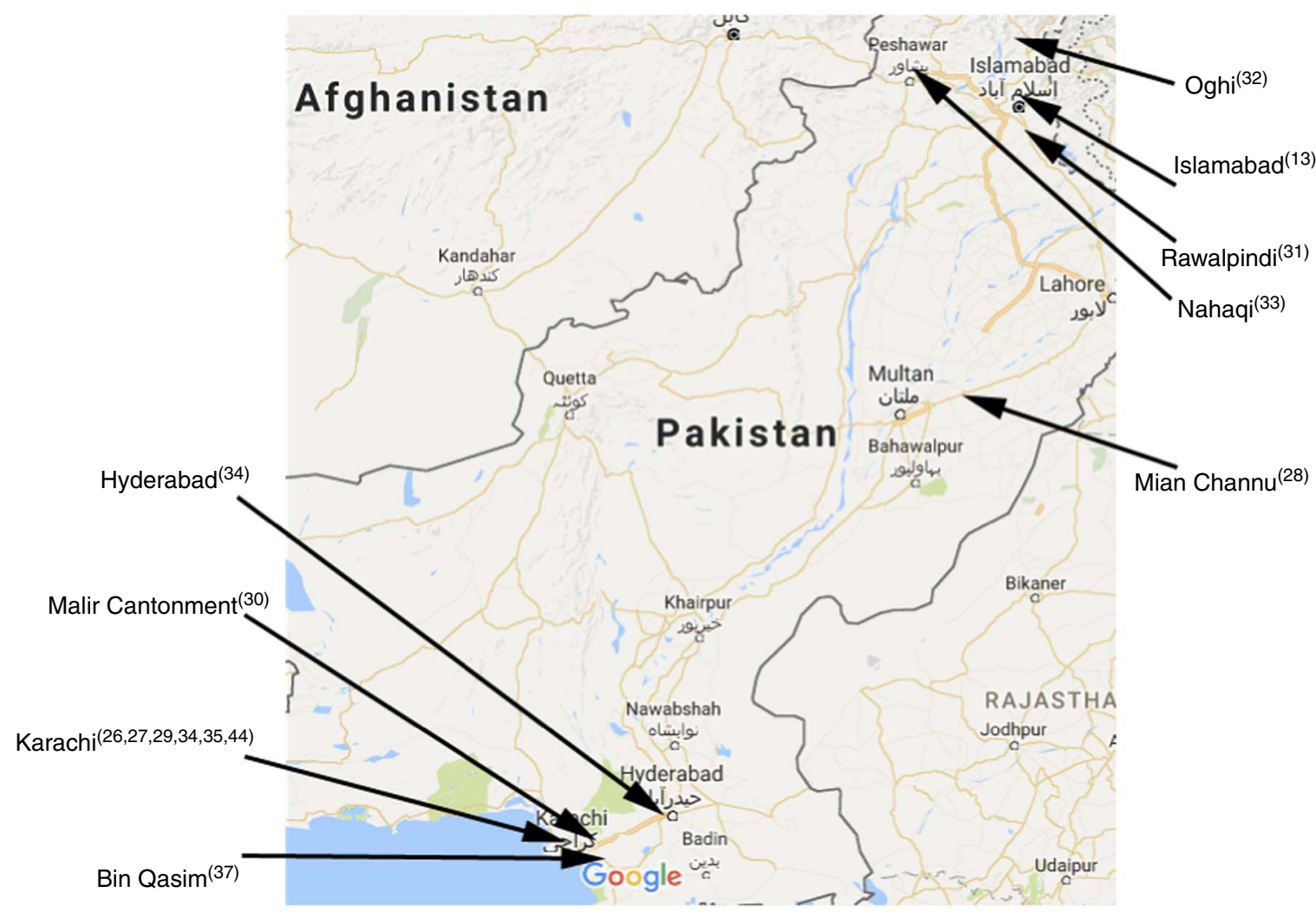

Fig. 2 (colour online) Location map of fourteen of the studies included the current systematic review (map courtesy of Google Maps; data (C) 2017 Google)

Table 2 Weight of evidence awarded to each study in the current systematic review

\begin{tabular}{|c|c|c|c|c|}
\hline \multirow[b]{2}{*}{ Study } & $\begin{array}{l}\text { Weight of } \\
\text { Evidence } A\end{array}$ & $\begin{array}{l}\text { Weight of } \\
\text { Evidence B }\end{array}$ & $\begin{array}{l}\text { Weight of } \\
\text { Evidence C }\end{array}$ & $\begin{array}{l}\text { Weight of } \\
\text { Evidence D }\end{array}$ \\
\hline & $\begin{array}{l}\text { Quality of } \\
\text { methodology } \\
\text { (accuracy, } \\
\text { coherency and } \\
\text { transparency of } \\
\text { the evidence) }\end{array}$ & $\begin{array}{c}\text { Relevance of } \\
\text { methodology } \\
\text { (appropriateness of } \\
\text { the methodology for } \\
\text { answering the review } \\
\text { question) }\end{array}$ & $\begin{array}{l}\text { Relevance of } \\
\text { evidence to the } \\
\text { review question } \\
\text { (relevance of the } \\
\text { focus of the evidence } \\
\text { for answering the } \\
\text { review question) }\end{array}$ & $\begin{array}{l}\text { Overall weight of evidence } \\
\text { (overall assessment of the } \\
\text { extent to which the study } \\
\text { provides evidence to answer } \\
\text { the review question) }\end{array}$ \\
\hline Ahmed et al. ${ }^{(32)}$ & L & M & M & M \\
\hline Dev et al. ${ }^{(34)}$ & $\mathrm{H}$ & $\mathrm{H}$ & $\mathrm{H}$ & $\mathrm{H}$ \\
\hline Dykes et al. ${ }^{(33)}$ & L & M & M & $M$ \\
\hline $\operatorname{Hanif}^{(14)}$ & $M$ & $\mathrm{M}$ & $\mathrm{M}$ & $M$ \\
\hline Hazir et al. ${ }^{(15)}$ & $\mathrm{H}$ & $\mathrm{M}$ & $\mathrm{H}$ & $\mathrm{H}$ \\
\hline Krebs et al. ${ }^{(26)}$ & M & M & M & $M$ \\
\hline Liaqat et al. ${ }^{(13)}$ & M & M & M & M \\
\hline Lingam et al. ${ }^{(31)}$ & $M$ & $\mathrm{H}$ & $\mathrm{H}$ & $\mathrm{H}$ \\
\hline Mehkari et al. ${ }^{(27)}$ & $\mathrm{H}$ & $M$ & $\mathrm{H}$ & $\mathrm{H}$ \\
\hline Memon et al. ${ }^{(36)}$ & $M$ & $\mathrm{H}$ & $\mathrm{H}$ & $\mathrm{H}$ \\
\hline Mohsin et al. ${ }^{(35)}$ & $M$ & $\mathrm{H}$ & $\mathrm{H}$ & $\mathrm{H}$ \\
\hline Premji et al. ${ }^{(37)}$ & M & M & $\mathrm{L}$ & M \\
\hline Sarwar ${ }^{(28)}$ & $\mathrm{H}$ & $\mathrm{H}$ & $\mathrm{H}$ & $\mathrm{H}$ \\
\hline Senarath et al. ${ }^{(16)}$ & $\mathrm{H}$ & $\mathrm{H}$ & $M$ & $\mathrm{H}$ \\
\hline Shamim $^{(29)}$ & M & $M$ & $\mathrm{H}$ & $M$ \\
\hline Shamim et al. ${ }^{(30)}$ & $\mathrm{H}$ & $M$ & $M$ & $M$ \\
\hline Sultana et al. ${ }^{(44)}$ & $\mathrm{L}$ & M & $\mathrm{L}$ & $\mathrm{L}$ \\
\hline
\end{tabular}

L, low; M, medium; H, high.

and $49 \%$ with rice; at the time of the study, $84 \%$ were fed rice and $29 \%$ cereal $^{(28)}$. In comparison, Ahmed et al. $(\mathrm{WOE}=\mathrm{M}$ ) found that $10 \%$ were introduced to $\mathrm{CF}$ with cereal, and $20 \%$ currently were fed rice ${ }^{(32)}$. Mehkari et al. $(\mathrm{WOE}=\mathrm{H}$ ) listed common $\mathrm{CF}$ food items including daliya (porridge, 64\%), several made with rice such as kitchri 
Table 3 Foods utilized for complementary feeding in Pakistan, categorized into $\mathrm{WHO}$ food groups

\begin{tabular}{|c|c|}
\hline WHO classified food group & $\begin{array}{l}\text { Number of studies and } \\
\text { references }\end{array}$ \\
\hline Grains, roots and tubers & Nine studies ${ }^{(26-34)}$ \\
\hline Legumes and nuts & Six studies ${ }^{(26,27,29-31,34)}$ \\
\hline $\begin{array}{l}\text { Dairy products (e.g. milk, cheese, } \\
\text { yoghurt) }\end{array}$ & Five studies ${ }^{(26-28,32)}$ \\
\hline $\begin{array}{l}\text { Flesh foods (e.g. meat, fish, poultry, and } \\
\text { liver/organ meats) }\end{array}$ & Four studies ${ }^{(26,28-30)}$ \\
\hline Eggs & Four studies ${ }^{(26,28-30)}$ \\
\hline Vitamin A-rich fruits and vegetables & Zero studies \\
\hline Other fruits and vegetables & Eight studies ${ }^{(27-34)}$ \\
\hline
\end{tabular}

If type of fruit/vegetable was not provided, it was classified as 'other fruits and vegetables'.

(rice and pulses, 69\%) and kheer (rice with milk, 48\%), and mashed potato $(65 \%)^{(27)}$. Shamim $(\mathrm{WOE}=\mathrm{M})$ also listed kitchri, daliya/dayla and suji (a wheat derivative) as CF foods ${ }^{(29)}$. Lingam et al. $(\mathrm{WOE}=\mathrm{H})$ observed that Cerelac, a store-bought porridge, was common among affluent families, and in some families, it was mixed with boiled potatoes $^{(31)}$.

'Other fruits and vegetables' were mentioned in eight studies with none directly specifying use of 'vitamin A-rich fruits and vegetables'. Sarwar $($ WOE $=\mathrm{H})$ observed that $11 \%$ of infants aged 3-12 months were first introduced to CF with fruits and $11 \%$ with vegetables, and $60 \%$ were currently fed fruits and $47 \%$ vegetables ${ }^{(28)}$; while Ahmed et al. (WOE= M) noted that $30 \%$ were first weaned with fruits of any sort, while $30 \%$ were currently fed apples and $30 \%$ bananas $^{(32)}$. Banana was popular, with Shamim $(\mathrm{WOE}=\mathrm{M})$ finding that banana was the only fruit offered by participants, and that seasonal fresh fruit and vegetables were not offered at all ${ }^{(29)}$. Shamim et al. $(\mathrm{WOE}=\mathrm{M})$ and Dykes et al. $(\mathrm{WOE}=\mathrm{M})$ also observed the use of banana ${ }^{(30,33)}$.

'Legumes and nuts' were identified in six studies for CF, primarily through the use of pulses in kitchri, a dish made of pulses with rice. Dev et al. $($ WOE $=\mathrm{H}$ ) found that $93.0 \%$ of home-made food given by sampled mothers in Bhains Colony in Karachi contained kitchri, as did $42.6 \%$ of home-made food given in Bilal Colony ${ }^{(34)}$; and Mehkari et al. $(\mathrm{WOE}=\mathrm{H})$ found that $69 \cdot 1 \%$ of participants used kitchri for $\mathrm{CF}^{(27)}$. Shamim et al. $(\mathrm{WOE}=\mathrm{M})$, Shamim $(\mathrm{WOE}=\mathrm{M})$ and Lingam et al. $(\mathrm{WOE}=\mathrm{H})$ also listed kitchri as a weaning food ${ }^{(29-31)}$. Krebs et al. $(\mathrm{WOE}=\mathrm{M})$ described the use of beans and lentils, and groundnuts (peanuts) ${ }^{(26)}$.

In terms of 'dairy products', Sarwar $(\mathrm{WOE}=\mathrm{H})$ described the use of cow's milk by $37 \%$ of those sampled and Ahmed et al. (WOE $=$ M) described its use by $10 \%{ }^{(28,32)}$. Shamim (WOE $=$ M) described extensive use of milk-based cereals $^{(29)}$. Sarwar also found that $20 \%$ of infants were introduced to CF with eggs, and $44 \%$ were currently fed eggs $^{(27)}$, although conversely Shamim $(\mathrm{WOE}=\mathrm{M})$ claimed egg seldom comprises CF foods ${ }^{(29)}$.

The use of commercial foods was mentioned by six studies, with usage rates ranging from 11 to $52 \%$. Shamim
(WOE $=\mathrm{M}$ ) found that $52 \%$ of mothers used commercial cereals for $\mathrm{CF}^{(29)}$, while Mohsin et al. $(\mathrm{WOE}=\mathrm{H})$ reported that $46.4 \%$ used commercial food items in general ${ }^{(35)}$, and in Mehkari et al. $(\mathrm{WOE}=\mathrm{H})$ this proportion was $15 \%{ }^{(27)}$. Sarwar $(\mathrm{WOE}=\mathrm{H})$ claimed that $2 \%$ of infants were introduced to CF with sweet convenience foods, and at the time of the study $11 \%$ were regularly consuming savoury convenience foods and $20 \%$ sweet convenience foods ${ }^{(28)}$. Dev et al. $(\mathrm{WOE}=\mathrm{H})$ reported that $21 \%$ of mothers in Bilal Colony provided only shop-bought/processed CF compared with $37 \%$ in Bhains Colony, attributing this difference to the presence of a non-governmental organization in Bilal $^{(34)}$. Shamim et al. $(\mathrm{WOE}=\mathrm{M})$ also mentioned the use of commercial foods ${ }^{(30)}$. Sarwar and Mohsin et al. reported tea was used for CF, which is not part of any WHO recommended food group ${ }^{(28,35)}$.

\section{Iron-rich foods}

There was little information on consumption of Fe-rich foods. Use of flesh foods (meat, fish, poultry and liver/ organ meats) was mentioned in only four studies. In Sarwar $($ WOE $=\mathrm{H}), 2 \%$ of infants were first introduced to CF with meat, and at the time of the study $24 \%$ were fed with meat ${ }^{(28)}$. This is a similar proportion to Krebs et al. $(\mathrm{WOE}=\mathrm{M})$, who found that $22.2 \%$ were fed meat regularly ${ }^{(25)}$. Conversely, Shamim $(\mathrm{WOE}=\mathrm{M})$ claimed that meat was almost never used for $\mathrm{CF}^{(29)}$. Otherwise, Shamim et al. (WOE $=\mathrm{M}$ ) described fish as being given for $\mathrm{CF}$ 'regularly' in fishing villages, although it is considered too costly elsewhere ${ }^{(30)}$.

\section{Meal frequency}

Meal frequency was measured in four studies, with rates of MMF ranging from 35.7 to $55.8 \%$ across the studies. MMF is two times for 6-8 months, three times for 9-23 months and four times for 6-23 months (if not breast-fed) ${ }^{(14)}$.

Mohsin et al. $(\mathrm{WOE}=\mathrm{H})$ found that $55.8 \%$ of infants aged 0-2 years were fed solid foods three times daily, achieving MMF if paired with breast-feeding; they also found that $39.9 \%$ were fed twice daily (which would meet MMF only for 6-8-month-olds) and 2.2\% were fed only once daily ${ }^{(35)}$. Memon et al. (WOE $=\mathrm{H}$ ) found $50 \%$ of infants aged 12-23 months received complementary foods at the MMF optimal rate of three or four times daily ${ }^{(36)}$. Krebs et al. $(\mathrm{WOE}=\mathrm{M}$ ) found that $37 \cdot 7 \%$ of infants aged 5-9 months were fed three or more times daily, meaning at least this proportion at a minimum met MMF, and 50.7\% were fed once or twice daily ${ }^{(25)}$. Comparing two colonies in Karachi, Dev et al. $(\mathrm{WOE}=\mathrm{H})$ found that $48.3 \%$ were fed three or more times daily in Bilal Colony, but $35.7 \%$ in Bhains Colony; as many as 10.2 and $9.5 \%$ in the respective colonies were fed only once daily ${ }^{(34)}$.

\section{Timing of introducing complementary feeding}

Table 4 denotes a summary of timing of when CF was introduced across the studies. The most commonly listed 
Table 4 Timing of introduction of complementary feeding in Pakistan

\begin{tabular}{ll}
\hline Infant age & Number of studies and references \\
\hline$<3$ months & Three studies $^{(35-37)}$ \\
$3-6$ months & Eleven studies $^{(13,15,27-31,33-36)}$ \\
$6-9$ months & Nine studies $^{(13-16,27-29,31,34)}$ \\
$9-12$ months & Three studies $^{(13,29,34)}$ \\
$12-15$ months & One study $(34)$ \\
$15-18$ months & One study \\
$>18$ months & Zero studies \\
\hline
\end{tabular}

age for CF commencement was at 3-6 months (eleven studies), followed by 6-9 months of age, the optimal period (nine studies). The third most common were under 3 months of age and 9-12 months of age, both by three studies. One study described CF introduction between 1 and 2 years.

Based on the 2006-07 Pakistan DHS, Senarath et al. $(\mathrm{WOE}=\mathrm{H})$ noted that timely initiation of $\mathrm{CF}$ in Pakistan was the lowest (39\%) compared with other SA countries: India achieved $55 \%$, Nepal $70 \%$, Bangladesh $71 \%$ and Sri Lanka $84 \%^{(16)}$. There was little improvement in the timing of introducing CF in infants aged 6-9 months between 1990-91 (32.1\%) and 2006-07 (36.3\%) in the national DHS, and the timing of introducing CF was ranked as 'poor' by Hanif $(\mathrm{WOE}=\mathrm{M})^{(14)}$; Hazir et al. $(\mathrm{WOE}=\mathrm{H})$ found $60 \cdot 8 \%$ of Pakistani infants aged $6-8$ months had not commenced CF, with $10 \cdot 6 \%$ of infants starting CF earlier than the recommended time ${ }^{(15)}$.

Hazir et al. $(\mathrm{WOE}=\mathrm{H})$ found that urban respondents were more likely to practise early or timely $\mathrm{CF}$, with $13.8 \%$ giving $\mathrm{CF}$ at $3-5$ months and at $56.6 \%$ at 6-8 months ${ }^{(15)}$. Only $9 \cdot 1 \%$ of rural respondents gave CF at 3-5 months and only $33 \cdot 2 \%$ at 6-8 months ${ }^{(15)}$. Liaqat et al. (WOE $=\mathrm{M}$ ) observed $\mathrm{CF}$ starting as late as up to 12 months among $64 \%$ of uneducated respondents, compared with $17 \%$ of educated respondents ${ }^{(13)}$, and Shamim (WOE $=\mathrm{M}$ ) found that less educated mothers sometimes delayed $\mathrm{CF}$ until the infant was 1 year old ${ }^{(29)}$. Dev et al. $(\mathrm{WOE}=\mathrm{H})$ described CF beginning between 1 and 2 years for $15.3 \%$ in Bilal Colony and for $18.4 \%$ in Bhains Colony ${ }^{(34)}$.

\section{Food bygiene}

Two studies looked at hand-washing and found good compliance; Mohsin et al. $(\mathrm{WOE}=\mathrm{H})$ found that $92 \%$ of respondents washed hands before cooking ${ }^{(35)}$, which is similar to Mehkari et al. $(\mathrm{WOE}=\mathrm{H})$ where $98 \%$ practised hand-washing before feeding children ${ }^{(27)}$. However, Mohsin et al. also found that $71.7 \%$ did not boil drinkingwater $^{(34)}$

Meal preparation for infants was generally done together with other family cooking. Three studies described meal preparation, with Mohsin et al. $(\mathrm{WOE}=\mathrm{H})$ noting that $50 \%$ of the mothers were cooking complementary foods separately from adult foods and Memon et al.
$(\mathrm{WOE}=\mathrm{H})$ describing that only $33 \%$ of children aged 6-11 months were provided with meals especially prepared for them ${ }^{(35,36)}$. Only $25 \cdot 6 \%$ of mothers who home-cooked food prepared meals especially for the infant in Shamim $(\text { WOE }=M)^{(29)}$.

\section{Advice providers}

Nine studies discussed advice providers. Of these, eight studies highlighted the importance of advice from family and friends, and one indicated that advice from medical professionals predominated. Memon et al. $(\mathrm{WOE}=\mathrm{H})$ found that $78 \%$ of mothers in their sample were advised primarily by family members, compared with $22 \%$ by medical professionals ${ }^{(36)}$, and Sarwar $(\mathrm{WOE}=\mathrm{H})$ found that two-thirds of mothers received advice from family and friends on weaning(28). Six other studies similarly emphasized the importance of families and friends in giving advice for $\mathrm{CF}^{(13,29,32-34,37)}$. Mohsin et al. $(\mathrm{WOE}=\mathrm{H})$ was the one study that indicated otherwise, saying that doctors were the primary source of knowledge in the case of commercial complementary foods for $52.9 \%$, compared with $25.4 \%$ who consulted relatives and friends ${ }^{(35)}$. Three studies mentioned the media as another source ${ }^{(29,32,35)}$. Other sources included women's magazines in Ahmed et al. and extra-familial elders in Premji et al. ${ }^{(32,37)}$.

\section{Factors associated with complementary feeding practices}

We identified several factors influencing CFP. They are summarized in Table 5 as either a barrier or a promoter, and sub-categorized as acting at family or organizational level. Overall, eight promoters and fourteen barriers were identified.

\section{Promoters}

Five studies identified four promoters at the family level. Promoters were: more educated mothers (four studies); literate mothers (one study); mother who had more than four antenatal visits (one study); and high level of parenting support (one study).

The most commonly mentioned promoter was 'more educated mothers', identified in four studies ${ }^{(13,15,29,36)}$. A positive relationship between maternal education and nutritional status was described by Liaqat et al. $(\mathrm{WOE}=\mathrm{M})^{(13)}$, with Shamim $(\mathrm{WOE}=\mathrm{M})$ noting that some uneducated mothers delayed $\mathrm{CF}$ until their child was 1 year old ${ }^{(29)}$. Interestingly, while Memon $(\mathrm{WOE}=\mathrm{H})$ et al. noted that the probability of inappropriate CFP in uneducated mothers was 3.7 times higher than in educated mothers, there was no correlation between paternal education and $\mathrm{CFP}^{(36)}$.

Five studies identified four promoters at the organizational level. Promoters were: wealthy households (three studies); activity of non-governmental organization (one study); improved health education (one study); and urban households (one study). 
Table 5 Factors influencing complementary feeding (CF) practices in Pakistan

\begin{tabular}{|c|c|c|c|}
\hline \multicolumn{4}{|c|}{ Family level } \\
\hline Promoters & $\begin{array}{l}\text { Number of studies and } \\
\text { references }\end{array}$ & Barriers & $\begin{array}{l}\text { Number of studies and } \\
\text { references }\end{array}$ \\
\hline $\begin{array}{l}\text { More educated mothers } \\
\text { Literate mothers } \\
\text { Mother who had } 4+\text { antenatal visits } \\
\text { Having a high level of parenting support }\end{array}$ & $\begin{array}{l}\text { Four studies }{ }^{(13,15,29,36)} \\
\text { One study }(15) \\
\text { One study }(15) \\
\text { One study }^{(31)}\end{array}$ & $\begin{array}{l}\text { Lack of maternal knowledge of CF } \\
\text { Cultural beliefs } \\
\text { Higher parity of mother } \\
\text { Insufficient breast milk } \\
\text { Lack of maternal time } \\
\text { Mother in employment } \\
\text { Mother becomes pregnant during } \\
\text { CF period } \\
\text { Mothers who had < } 4 \text { antenatal visits } \\
\text { Difficulty getting the baby to feed } \\
\text { Delivery by caesarean section }\end{array}$ & $\begin{array}{l}\text { Five studies }^{(28,32,34-36)} \\
\text { Four studies }^{(29,31,35,37)} \\
\text { Three studies }^{(15,16,29)} \\
\text { Three studies }^{(29,33,36)} \\
\text { Two studies }^{(29,35)} \\
\text { Two studies }^{(15,27)} \\
\text { Two studies }^{(33,36)} \\
\text { One study }^{(15)} \\
\text { One study(33) } \\
\text { One study }\end{array}$ \\
\hline \multicolumn{4}{|c|}{ Organizational level } \\
\hline Promoters & $\begin{array}{l}\text { Number of studies and } \\
\text { references }\end{array}$ & Barriers & $\begin{array}{l}\text { Number of studies and } \\
\text { references }\end{array}$ \\
\hline $\begin{array}{l}\text { Wealthy households } \\
\text { NGO activity } \\
\text { Improved health education } \\
\text { Urban households }\end{array}$ & $\begin{array}{l}\text { Three studies }{ }^{(15,16,31)} \\
\text { One study } \\
\text { One study } \\
\text { One study } \\
\text { O(15) }\end{array}$ & $\begin{array}{l}\text { Household poverty } \\
\text { Food affordability and access } \\
\text { Poor advice from health workers } \\
\text { Rural households }\end{array}$ & $\begin{array}{l}\text { Six studies } \\
\text { Four studies }^{(13,15,16,31,32,37)} \\
\text { One study } \\
\text { One study }^{(15)}\end{array}$ \\
\hline
\end{tabular}

NGO, non-governmental organization.

The most identified promoter was wealthier households. Hazir et al. $(\mathrm{WOE}=\mathrm{H})$ found that the percentage of timely $\mathrm{CF}$ at 6-8 months was higher in richer and richest households, at 51.3 and $70.9 \%$, respectively, compared with poorest, poorer and middle households, which achieved rates of $28 \cdot 0,33 \cdot 7$ and $23 \cdot 1 \%$, respectively ${ }^{(15)}$. This association was also found in Senarath et al. $(\mathrm{WOE}=\mathrm{H})$ and Lingam et al. $(\mathrm{WOE}=\mathrm{H})^{(16,31)}$.

\section{Barriers}

Twelve studies identified ten barriers at the family level. Barriers were: lack of maternal knowledge on CF (five studies); cultural beliefs (four studies); higher parity of mother (three studies); insufficient breast milk (three studies); lack of maternal time (two studies); mother in employment (two studies); mother becomes pregnant during CF period (two studies); mother who had fewer than four antenatal visits (one study); delivery by caesarean section (one study); and difficulty getting the baby to feed (one study).

The most cited family-level barriers were lack of maternal knowledge on $\mathrm{CF}$ and cultural beliefs. In terms of inadequate knowledge, Memon et al. $(\mathrm{WOE}=\mathrm{H})$ found that $90 \%$ of mothers had inadequate knowledge on frequency of $\mathrm{CF}^{(36)}$, with large gaps in knowledge also reported by Mohsin et al. $(\mathrm{WOE}=\mathrm{H})^{(35)}$. Knowledge is not sufficient for good CF, however; Mehkari et al. $(\mathrm{WOE}=\mathrm{H})$ reported that although $78 \%$ of female health-care professionals knew WHO guidelines on initiating CF at 6 months, only 53\% adhered to them ${ }^{(27)}$. Regarding cultural beliefs, ideas about certain foods being 'hot' or 'cold' inhibited dietary diversity. Mohsin et al. $(\mathrm{WOE}=\mathrm{H})$ listed 'hot' foods including bread, meat, potato and egg, and 'cold' foods including rice, curd and banana, and observed that $41 \%$ of caregivers would avoid 'cold' foods in winter and during illness ${ }^{(35)}$. Premji et al. $(\mathrm{WOE}=\mathrm{M})$ also found that cultural beliefs inhibit $\mathrm{CF}$ during illness ${ }^{(37)}$.

In total, nine studies identified four barriers at the organizational level. Barriers were: household poverty (six studies); food affordability and access (four studies); poor advice from health workers (one study); and rural households (one study).

The barrier posed by being poor was the most popular influencing factor either positively or negatively. Hazir et al. $(\mathrm{WOE}=\mathrm{H})$ and Senarath $(\mathrm{WOE}=\mathrm{H})$ both identified that $\mathrm{CF}$ initiation was delayed significantly in the middle to poorest wealth index compared with the richest in Pakistan ${ }^{(15,16)}$. Dykes et al. $(\mathrm{WOE}=\mathrm{M})$ described how women felt that poverty stopped them being able to adequately feed their children $^{(33)}$, and Liaqat et al. $(\mathrm{WOE}=\mathrm{M})$ named poverty as one of the main reasons for inappropriate practices ${ }^{(13)}$. Cost and accessibility was the second most identified barrier, with Shamim $(\mathrm{WOE}=\mathrm{M})$ finding that meat and seasonal fruits were rarely given due to their cost and low availability, and Shamim et al. $(\mathrm{WOE}=\mathrm{M})$ observing that expensive ready-to-make cereals were often overdiluted ${ }^{(29,30)}$.

\section{Discussion}

To our knowledge, the present is the first systematic review to assess CFP in Pakistan. We identified that CFP in many Pakistani SA families were not meeting WHO IYCF 
standards on minimum dietary diversity, meal frequency and timing of introducing $\mathrm{CF}$.

\section{Implications of key findings}

Grains, roots, tubers and legumes appear to predominate for $\mathrm{CF}$ in Pakistan. It is concerning that only five of nine studies discussing dietary diversity described CF foods covering four of the seven groups recommended in the WHO IYCF guidelines; the true number of infants consuming foods across these four groups is likely to be low. No study directly addressed rates of meeting MDD requirements. Inappropriate $\mathrm{CF}$ foods were sometimes described, such as tea and crackers mentioned by Sarwar $(\mathrm{WOE}=\mathrm{H})$ and Shamim et al. $(\mathrm{WOE}=\mathrm{M})^{(28,30)}$. Besides reducing appetite, tea tannin impairs Fe absorption which may contribute to anaemia ${ }^{(38)}$. The widespread use of commercial complementary food items in Pakistan due to doctors' recommendation, perceptions that this is 'best for the baby', media influence and easy availability of such foods is another issue which must be tackled ${ }^{(35)}$. Only two studies provided information on CF related hygiene, which both discussed hand-washing ${ }^{(27,35)}$. Food hygiene is an emerging concern in Pakistan and we recommend future studies collect data on this important topic $^{(39)}$.

In terms of MMF, even when $\mathrm{CF}$ is initiated it is often not given at the optimum rate of three or four times daily. Increased presence of non-governmental organizations and medical staff in local factories may help improve CF practices; Dev et al. $(\mathrm{WOE}=\mathrm{H})$ examined $\mathrm{CF}$ in two socioeconomically similar colonies in Karachi and linked the superior CF practices in Bilal Colony, where $48.3 \%$ met MMF compared with $35.7 \%$ in Bhains Colony, to these factors $^{(34)}$. This approach could help inform interventions to improve MMF in other areas.

Timing of $\mathrm{CF}$ is a problem in Pakistan, which has the lowest proportion of timely CF among all the SA countries ${ }^{(16)}$. Premature $\mathrm{CF}$ is associated with increased risk of infection according to Shamim et al. $(\mathrm{WOE}=\mathrm{M})^{(30)}$, and Sarwar $(\mathrm{WOE}=\mathrm{H})$ found late introduction of $\mathrm{CF}$ affected growth and could lead to defiant eating behaviours including rejection of food and difficulty in learning to masticate $^{(28)}$. Measures to increase knowledge about timing of CF can help mitigate these health effects.

The eight promoters identified in the present review can help inform interventions to improve CF in Pakistan. One in particular, improved health education, could help address some familial barriers such as a lack of knowledge or cultural beliefs. Sarwar (WOE $=$ H) found that mothers wanted information in traditional languages to help improve their care practices, and also valued group discussions and demonstrations ${ }^{(28)}$. It was thought that such sessions, by being more interactive, could address points of confusion. Another health-care intervention, cognitive behavioural therapy, has been trialled to target deeply embedded beliefs around breast-feeding in a socio-economically disadvantaged district of Pakistan ${ }^{(40)}$. By building a therapeutic relationship with the mother, this holistic intervention was used successfully to deliver messages on breast-feeding. Active methods to encourage mothers to practise correct $\mathrm{CF}$ behaviour could be very effective, and should be practical while respecting the local customs and traditional culture ${ }^{(28)}$.

Fourteen separate barriers to appropriate CF were identified. Among the familial barriers, the listing of 'mother in employment' as a barrier is concerning and suggests that more needs to be done to support working mothers. Memon et al. (WOE $=\mathrm{H}$ ) suggest workplace policies should be modified to provide social support and motivation for breast-feeding among working mothers ${ }^{(36)}$. A further very notable barrier is the absence of knowledge on appropriate $\mathrm{CF}$ at all levels. Previous studies have shown that educational and behaviour change interventions successfully improve CF practices ${ }^{(41,42)}$. Training should be provided in order for health-care professionals to deliver consistent information, as properly trained professionals can improve feeding practices and outcomes in children aged 6-24 months ${ }^{(43)}$. Given that eight of the nine studies that discussed advice providers highlighted the importance of family and friends, it seems advisable that interventions should target whole communities, not mothers alone.

\section{Strengths and limitations}

The strengths of our systematic review are derived from searching a large number of databases utilizing very broad search strings, performing an updated search in June 2016, and having two reviewers undertake study selection, data extraction and quality assessment.

Key limitations include the exclusion of: (i) papers that focused solely on children over 2 years of age, where CFP described in their younger years may have been missed; (ii) papers published before the year 2000 at full-text review; and (iii) papers not published in English, which would have added to the diversity of CFP described. These limitations mean the review is potentially not exhaustive; however, we were able to screen a total of 45712 abstracts across the four reviews. This is, to our knowledge, the most comprehensive review of the literature to date.

In several studies where there was overlap between children under and over 2 years of age and/or SA by Indian, Pakistani and Bangladeshi origin, CFP described and attributed to the whole study population may be incorrect. Furthermore, we did not assess the quantities of the foods used, only the frequency with which they appeared in the studies.

While we excluded interventional studies that may have described CFP in their study population, this is unlikely to be the primary focus of such studies and therefore unlikely to have affected our systematic review significantly. 


\section{Conclusion}

Despite adoption of the WHO IYCF guidelines, inadequate CFP remain in families across Pakistan. While Pakistan has made giant strides in decreasing child mortality over the last two decades, further work is required to improve CFP to reduce this further, as well as to tackle rates of wasting, stunting and underweight. The current systematic review has highlighted CFP and the factors that influence them, paving the way for development of evidence-based interventions.

\section{Acknowledgements}

Acknowledgements: The authors would like to thank Lucy Stephenson, Alexandra Robinson, Melanie Flury, Taimur Shafi, Atul Singhal, Rani Chowdhary, Charlotte HamlynWilliams, Prerna Bhasin, Aaron O'Callaghan and Conor Fee for assisting in the systematic review. Financial support: This research received no specific grant from any funding agency in the public, commercial or not-for-profit sectors. L.M. is funded by a National Institute for Health Research (NIHR) Doctoral Research Fellowship (grant number DRF-2014-07-005); S.A. is funded by the NIHR Collaboration for Leadership in Applied Health Research and Care (CLAHRC) North Thames at Bart's Health NHS Trust; and M.L. is partly supported by the NIHR CLAHRC North Thames at Bart's Health NHS Trust. NIHR had no role in the design, analysis or writing of this article. Conflict of interest: The authors declare they have no conflicts of interest. Authorship: L.M., R.L. and M.L. conceived and participated in the design of the study. L.M., A.S., A.D., E.C.A., J.Y.K., A.P. and S.A. coordinated and undertook the review. All authors performed the data interpretation and contributed equally to write the draft, read and approved the final manuscript. Ethics of buman subject participation: Not applicable.

\section{References}

1. UNICEF, World Health Organization, World Bank et al. (2015) Levels and Trends in Child Mortality: Report 2015. New York: UNICEF.

2. Agha D, Maqbool S \& Anwar S (2005) Is poverty or lack of nutrition awareness the main cause of malnutrition in children? Pak Pediatr J 29, 63-67.

3. Corvalan C, Dangour A \& Uauy R (2008) Need to address all forms of childhood malnutrition with a common agenda. Arch Dis Child 93, 361-362.

4. UNICEF South Asia (2015) Progress Report: Six Headline Results for Children in South Asia: Stop Stunting. Kathmandu: UNICEF Regional Office for South Asia.

5. Misra A \& Shrivastava U (2013) Obesity and dyslipidemia in South Asians. Nutrients 5, 2708-2733.

6. Bhagowalia P, Chen SE \& Masters WA (2011) Effects and determinants of mild underweight among preschool children across countries and over time. Econ Hum Biol 9, 66-77.

7. Netuveli G, Hurwitz B, Levy M et al. (2005) Ethnic variations in UK asthma frequency, morbidity, and health-service use: a systematic review and meta-analysis. Lancet 365, 312-317.
8. Rodgers RF, Paxton SJ, Massey R et al. (2013) Maternal feeding practices predict weight gain and obesogenic eating behaviors in young children: a prospective study. Int J Behav Nutr Phys Act 10, 24.

9. Jones G, Steketee RW, Black RE et al. (2003) How many child deaths can we prevent this year? Lancet $\mathbf{3 6 2}$, 65-71.

10. Das JK, Achakzai ABK \& Bhutta ZA (2016) Stop stunting: Pakistan perspective on how this could be realized. Matern Child Nutr 12, 253-256.

11. World Health Organization (2016) Appropriate complementary feeding. http://www.who.int/elena/titles/ complementary_feeding/en/ (accessed October 2016).

12. World Health Organization (2009) Infant and Young Child Feeding: Model Chapter for Textbooks for Medical Students and Allied Health Professionals. Geneva: WHO.

13. Liaqat P, Rizvi MA, Qayyum A et al. (2007) Association between complementary feeding practice and mothers' education status in Islamabad. J Hum Nutr Diet 20, 340-344.

14. Hanif H (2011) Trends in breastfeeding and complementary feeding practices in Pakistan, 1990-2007. Int Breastfeed J 6, 15.

15. Hazir T, Senarath U, Agho K et al. (2012) Determinants of inappropriate timing of introducing solid, semi-solid or soft food to infants in Pakistan: secondary data analysis of Demographic and Health Survey 2006-2007. Matern Child Nutr 8, Suppl. 1, 78-88.

16. Senarath U, Agho KE, Akram DES et al. (2012) Comparisons of complementary feeding indicators and associated factors in children aged 6-23 months across five South Asian countries. Matern Child Nutr 8, Suppl. 1, 89-106.

17. National Institute of Population Studies (Pakistan) \& ICF International (2013) Pakistan Demographic and Health Survey 2012-13. Calverton, MD: National Institute of Population Studies \& ICF International.

18. Manikam L, Robinson A, Kuah JY et al. (2017) A systematic review of complementary feeding practices in South Asian infants and young children: the Bangladesh perspective. BMC Nutr 3, 56.

19. Manikam L, Prasad A, Dharmaratnam A et al. (2017) Systematic review of infant and young child complementary feeding practices in South Asian families: the India perspective. Public Health Nutr (Epublication ahead of print version, doi: 10.1017/S136898001700297X).

20. World Health Organization (2010) Indicators for Assessing Infant and Young Child Feeding Practices. Geneva: WHO.

21. Centre for Reviews and Dissemination (2009) Systematic reviews: CRD's guidance for undertaking reviews in health care. https://www.york.ac.uk/media/crd/Systematic_ Reviews.pdf (accessed October 2017).

22. Dixon-Woods M, Agarwal S, Jones D et al. (2005) Synthesising qualitative and quantitative evidence: a review of possible methods. J Health Serv Res Policy 10, 45-53.

23. Collins JA \& Fauser BCJM (2005) Balancing the strengths of systematic and narrative reviews. Hum Reprod Update 11, 103-104.

24. Popay J, Roberts H, Sowden A et al. (2006) Guidance on the Conduct of Narrative Synthesis in Systematic Reviews: A Product from the ESRC Methods Programme. http://www. lancaster.ac.uk/shm/research/nssr/research/dissemination/ publications/NS_Synthesis_Guidance_v1.pdf (accessed October 2017).

25. Gough D (2007) Weight of Evidence: a framework for the appraisal of the quality and relevance of evidence. Res Papers Educ 22, 213-228.

26. Krebs NF, Mazariegos M, Tshefu A et al. (2011) Meat consumption is associated with less stunting among toddlers in four diverse low-income settings. Food Nutr Bull 32, 185-191. 
27. Mehkari S, Zehra N, Yasin H et al. (2014) Breastfeeding and weaning: awareness and practices among female health providers working in a tertiary care hospital of KarachiPakistan. Int J Womens Health Reprod Sci 2, 281-286.

28. Sarwar T (2002) Infant feeding practices of Pakistani mothers in England and Pakistan. J Hum Nutr Diet 15, 419-428.

29. Shamim S (2005) Weaning practices in peri-urban low socioeconomic groups. J Coll Physicians Surg Pak 15, 129-132.

30. Shamim S, Naz F, Waseem Jamalvi S et al. (2006) Effects of weaning period on nutritional status of children. $J$ Coll Physicians Surg Pak 16, 529-531.

31. Lingam R, Gupta P, Zafar S et al. (2014) Understanding care and feeding practices: building blocks for a sustainable intervention in India and Pakistan. Ann N Y Acad Sci 1308, 204-217.

32. Ahmed I, Farooq N, Jadoon H et al. (2001) Lactation, breastfeeding supplementation and nutrition. J Ayub Med Coll Abbottabad 13, 34-37.

33. Dykes F, Lhussier M, Bangash S et al. (2012) Exploring and optimising maternal and infant nutrition in North West Pakistan. Midwifery 28, 831-835.

34. Dev M, Shaikh A, Shaikh R et al. (2013) Knowledge of complementary feeding of mothers having infants younger than 2 years of age - a community based study. Pak Pediatr J 37, 149 .

35. Mohsin SS, Shaikh AS, Shaikh R et al. (2014) Knowledge attitude and practices of mothers regarding complementary feeding. J Dow Univ Health Sci Karachi 8, 21-25.

36. Memon S, Shaikh S, Kousar T et al. (2010) Assessment of infant feeding practices at a tertiary care hospital. J Pak Med Assoc 60, 1010-1015.
37. Premji S, Khowaja S, Meherali S et al. (2014) Sociocultural influences on newborn health in the first 6 weeks of life: qualitative study in a fishing village in Karachi, Pakistan. BMC Pregnancy Childbirth 14, 232.

38. Zijp IM, Korver O \& Tijburg LB (2000) Effect of tea and other dietary factors on iron absorption. Crit Rev Food Sci Nutr 40, 371-398.

39. Akhtar S (2015) Food safety challenges - a Pakistan's perspective. Crit Rev Food Sci Nutr 55, 219-226.

40. Rahman A, Haq Z, Sikander S et al. (2012) Using cognitivebehavioural techniques to improve exclusive breastfeeding in a low-literacy disadvantaged population. Matern Child Nutr 8, 57-71.

41. Imdad A, Yakoob MY \& Bhutta ZA (2011) Impact of maternal education about complementary feeding and provision of complementary foods on child growth in developing countries. BMC Public Health 11, Suppl. 3, S25.

42. Shi L \& Zhang J (2010) Recent evidence of the effectiveness of educational interventions for improving complementary feeding practices in developing countries. J Trop Pediatr 57, 91-98.

43. Zaman S, Ashraf RN \& Martines J (2008) Training in complementary feeding counselling of healthcare workers and its influence on maternal behaviours and child growth: a cluster-randomized controlled trial in Lahore, Pakistan. J Health Popul Nutr 26, 210-222.

44. Sultana N, Khurshid R, Malik A et al. (2011) Breast feeding, weaning practices and the education status of mothers during the first 4-6 months of life: a survey. Pak Pediatr J 35, 199. 